\title{
The Role of Commercial Banks in a Society and the Possibility of Participation in Financing Environmentally Oriented Investment Projects on the Example of Mongolia
}

\author{
Ganbat Khaliun
}

\begin{abstract}
This paper deals with investment activities of commercial banks and there is shown the possibility of participation in financing ecologically oriented investment projects is studied. Moreover, the investment potential of Mongolian banks is analyzed.
\end{abstract}

Index Terms-Ecologically oriented investment projects, credit-investment potential, investment activity of banks, Mongolia.

\section{INTRODUCTION}

In recent decades, there were significant changes in the paradigm of social development and its relation to global worldwide problems. There is a growing trend of population, who pays attention to the ecology and tries to be environmentally friendly. Ecological thinking extends to all spheres of human activity, covering the increasing number of world's population and motivating people to increase their responsibility towards the environment.

At the same time interest in the scientific community is steadily increasing to the new direction of development of financial mechanisms for regulating environmental impact. The reason for this has become a modern need of society, "maturity" of environmental awareness, the experience of relevant research that led to the most efficient use of mechanisms of mixed load control on the ecosystem, including regulatory measures, administrative control, measures of direct regulation and economic incentives through market mechanisms and insurance. Ecology becomes the source, the cause of innovative development and implementation of the innovation process.

The problem of environmentally oriented investment, due to its important role in the implementation of "green" social reproduction in recent years, has become one of the most important and widely discussed in the scientific and practical sphere. The subject, methodology and practical use of this term is always debated, as well as its relation with other categories, such as income, inflation, economic efficiency, equity market and others. Commercial banks that are main participants of financial sector can play a role of socially responsible organization towards the environment by financing "green" projects in order to help in creating "green economy" in modern society.

Manuscript received December 24, 2014; revised February 29, 2015.

Ganbat Khaliun is with Plekhanov Russian University of Economics Mongolia (e-mail: khaliuka90@mail.ru).

\section{INVESTMENT BANKING ACTIVITY AND MONGOLIA'S BANKING SECTOR}

Investment Banking - is a narrower concept than investment intermediary for commercial banks. It is distinguished from bank investment intermediary by the fact that in this case the investment is determined by the initiative of banks themselves. At the same time in the provision of its brokerage services, it is guided by motives that are not directly related to the investment market, but thanks to these services, customers can implement investment transactions of securities. Here, banks perform general organizational functions of capital market intermediaries.

Based on the fact that investment is financing a capital in order to its subsequent augmentation, it should be noted that capital gain should be sufficient to compensate commercial banks refuse in financing other alternative resources for investment in money market, reward and compensate the risk of loss from inflation rate in the forthcoming investment period [1].

Investment banking activity is operated in the investment market, which is divided into a number of relatively independent segments, including market of real investment objects, financial investment market objects and objects of innovative investment market.

In a market economy, the implementation of investment cannot be considered as an "arbitrary" form of the bank's activities in a sense that the bank may execute or not this kind of operation. Failure in investment inevitably leads to the loss of competitive position of the bank as a financial intermediary. Therefore, all possible investments can be divided into two groups [2]:

1) Passive investment, that is capable in providing, at best, no deterioration of the average profitability of investment in a various types of projects in general by the bank or financial service market.

2) Active investments, that enhance the competitiveness and profitability in a relation to the earlier achieved results by the investment to new technologies, organize financing best-selling new product groups, capturing with their help new markets or acquisition competing firms through targeted investments.

Thus, investment activity of banks in market conditions is carried out by an economic entity in the investment market with unconditional and main purpose of making a profit.

Effective development of a real sector of the economy in many ways provides a complete and affordable financing investment projects. The sources of such funding are funds formed both within the enterprise and beyond. 
Located between Russia and China, Mongolia is one of the most exciting investment opportunities currently available in the world. With over $\$ 10$ billion USD already committed for deep mining and infrastructure projects, Mongolia remains the final frontier for investors to benefit from continual and rapid growth [3].

If we consider the banking system of Mongolia, by the end of 2014 the banking sector is comprised of 14 commercial banks operating through their 1382 branches and units in Mongolia. The sector wide number of depositors grew by 264 thousand and reached a total of 2.1 million, while the number of borrowers grew by 8.4 thousand to reach 614.6 thousand.

The confidence in the banking sector is growing. In 2014, the amount of capital in the banking sector totaled $\mathrm{MNT}^{1} 1.3$ trillion, a $33.9 \%$ increase of MNT 320.9 billion, while the risk weighted assets of the banking sector rose by $23.4 \%$ or MNT 1.5 trillion and reached MNT 7.8 trillion. The increase of banking capital was largely due to the profitability improvements of banks. At the end of 2014, banks' net profits were MNT 193.1 billion, a 12\% increase of MNT 20.6 billion from the previous year. Despite the profitability improvements, due to the high growth rate of the banking capital, the core profitability ratio declined. That is, the return on assets of the banking sector declined by 0.3 percentage points and leveled 2.3 points, and the return on capital also fell to 15.2 points, a decline of 3.4 percentage points compared with the previous year of 2014 .

TABLE I: FORECAST OF BASIC INDICATORS IN 2015 OF MONGOLIA

\begin{tabular}{lcc}
\hline \hline Indicators & 2014 preliminary performance forecast & 2015 \\
\hline GDP growth & $6.5 \%$ & $5 \%$ \\
Inflation & $12 \%$ & $12 \%$ \\
Loan rate & $18 \%$ & $19 \%$ \\
Bad loan & $5 \%$ & $6 \%$ \\
\hline \hline
\end{tabular}

Moreover, some basic indicators of Mongolian economy forecast is shown in Table I [6].

In 2013 were observed a high growth in banking sector assets, an increase of $68.2 \%$ from the previous year totaling MNT 19.3 trillion. The key components of the asset growth were increase in short-term investments and loans outstanding. Particularly, as of the end of 2013, short-term investments in Government bonds totaled MNT 400.6 billion with an increase of $24.2 \%$ (y-o-y), whereas the short-term investments in Central bank bills increased by $114 \%$ from the previous year totaling MNT 1.6 trillion.

In terms of asset composition, $53.1 \%$ of total banking sector assets is composed of loans outstanding, $22.3 \%$ of cash and cash equivalents, $11.5 \%$ of short-term investments, $8.7 \%$ of long-term investments and the remaining $4.3 \%$ were other investments. Equity investments were $0.6 \%$ of short-term investments indicating no direct influence from the equities market in the banking sector assets.

As a major asset category of banking sector, loans outstanding in 2013 increased by MNT 3.6 trillion or $52.6 \%$ from the previous year amounting to MNT 10.4 trillion in total. In regards to the quality of total loans outstanding, $96.6 \%$ or MNT 10 trillion were performing, $1.1 \%$ or MNT 115.6 billion was classified as past due and the remaining $2.5 \%$ equaling MNT 261.4 billion were non-performing.

${ }^{1}$ Mongolian National Tugriks
Although the main loan quality indicator-non-performing loans increased by MNT 113.4 billion or $76.4 \%$ from the previous year of 2013, non-performing loans to total loans outstanding ratio remained relatively stable with an increase of $0.3 \%$ from the previous year. In terms of loan financing in economic sectors, real estate and construction sector accounted for $30.1 \%$ of total loans, $16.3 \%$ in wholesale and retail sector, $12.4 \%$ in mining, $10.1 \%$ in manufacturing and the remaining $31.1 \%$ were in other sectors. Loan financing as a share of total loans has increased the most in real estate and construction sector by 3.1 percentage points while in other sectors declined by 2.5 percentage points. The factors influencing the loan repayment include foreign and local economic conditions, business environment, foreign currency flows, investments, currency exchange rate, inflation, manufacturing, service etc. In 2013, Mongolia faced economic difficulties due to the decline in foreign currency inflow by USD 4 billion and sharp decrease in net foreign assets. This has raised the risks of increasing non-performing loans. In order to buffer from the credit risk losses, banks had loan loss reserves of $71.6 \%$ of total non-performing loans or MNT 187.2 billion as of the end of 2013. Non-performing loans adjusted by the loan loss provision fund equaled MNT 74.2 billion or $0.7 \%$ of total loans outstanding, indicating adequate level of risk bearing capacity in the banking system.

At the end of 2013, total liabilities in banking sector increased by MNT 7.4 trillion or $68.3 \%$ from the previous year totaling MNT 17.5 trillion. Key determinant of the above mentioned growth in liabilities was increase in funds from financial institutions, particularly; the case that loans extended by Central bank to commercial banks under the Economic Stabilization Policy reached MNT 2.8 trillion. In terms of structure, $43.4 \%$ of total liabilities comprised of savings, $16.9 \%$ current accounts, $28.8 \%$ funds from non-bank financial institutions and the remaining $10.8 \%$ were other sources.

Deposits, the main funding source in banking sector, increased by MNT 2.5 trillion or $49.7 \%$ from the previous year amounting to MNT 7.6 trillion at the end of 2013. Of which, MNT 5.1 trillion or $67.3 \%$ were from private sectors: individuals, institutions and foreign residents. Although deposits from private sectors increased by $16.2 \%$ or MNT 714.1 billion from the previous year, its share in total loans declined by 19.4 percentage points. Short-run unstable current accounts outstanding reached MNT 3 trillion, increasing 28.2\% or MNT 652.9 billion from 2012. Totaling MNT 2 trillion and increasing 53.6\% or MNT 691 billion from the previous year, increase in current accounts from private sectors was relatively high in 2013.

By the end of 2013, share of foreign currency funds in aggregate sources of funds in banking system declined by 8.6 percentage points from 2012 and amounted to $30.6 \%$ due to the sharp decline in foreign currency flows throughout several quarters. Furthermore, share of foreign currency loans in total loans was $27.5 \%$, declined by 5.1 percentage points from the previous year. This has direct influence from the decline of borrowers' interest in borrowing in foreign currency due to the foreign exchange rate fluctuations.

Moreover, in 2013 banking system loan to deposits including the current accounts ratio increased by 6.2 
percentage points from last year accounting for $98.3 \%$. In other words, there is a tendency of increase in activities of funding loans by short-term sources of funds. For instance, by the end of $2011,80.9 \%$ of funds concentrated in banking system from other parties were current accounts and deposits, while at the end of 2012 this has decreased to $72.8 \%$, and $60.4 \%$ in 2013. However, Net Stable Funding Ratio (NSFR) of $129.5 \%$ as of 2013 indicates that stable sources of funds such as current accounts, deposits, equity, interbank loans with maturity more than 1 year are accounting for majority of total funds. (Fig. 1.)

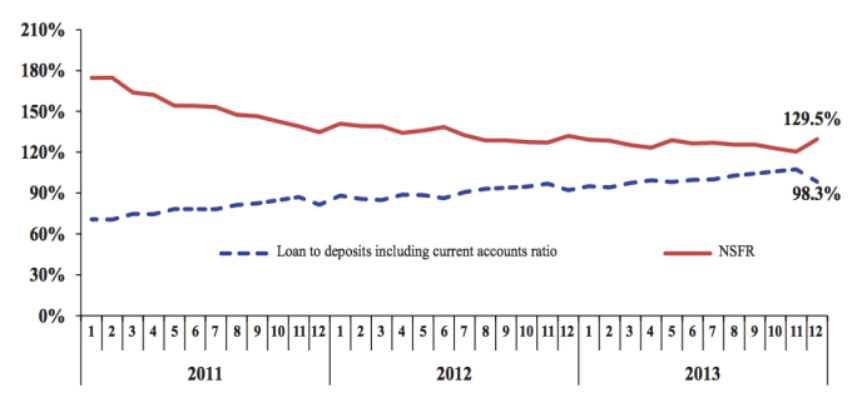

Fig. 1. Stable funding ratios.

Analysis of modern practice of Mongolia shows that enterprises funded about $35 \%$ of investment needs with their own funds and the remained part of fund is attracted from various external sources. The most powerful source of external financing investment in terms of volume and capacity are funds generated by financial intermediaries. Key financial intermediaries in Russia] and Mongolia - are commercial banks. Their leading role in the financial support of investment processes is primarily due to the availability of sufficient resource potential. So, in 2014, the assets of Mongolian banks accounted for $20 \%$ of GDP, and the market of bank loans $12 \%$.

Moreover, in Mongolia the banking sector alone constitutes $96 \%$ of the financial system and addressing banking sector and monetary policy issues may not be sufficient to ensure financial stability. (Fig. 2) Therefore, a balanced development in the financial sub-sectors, an effective and integrated macro and micro policies aimed at ensuring long-term sustainable economic growth, an appropriate and structured financial institutional arrangements and infrastructure reforms coherent with socio-economic development objectives, and a positive public understanding of the financial sector have to be considered as a general framework in ensuring financial stability. This tendency has spread around the world, and created significant changes [5].

\section{PROBLEM AND SOLUTION}

The most urgent challenge facing modern man is the preservation and protection of the natural environment. Modern man has a serious detrimental impact on the environment and thereby reduces the economic potential of individual countries and the global community. Therefore a priority objective to create the conditions for long-term socio-economic development of Mongolia is to improve the quality of the environment and ecological conditions of human life.
Development of industrial production, transport, agrarian revolution in agriculture caused by the rapid scientific and technological progress of mankind, had a detrimental impact on environment and led to significant changes of the carbon cycle, nitrogen, minerals, water, oxygen on the Earth's biosphere, desertification, air pollution and soil erosion.

According to environmental monitoring services Hydrometeorology of Mongolia, in 2014 alone recorded 126 cases of extremely high and high air pollution, 14 cases of which of accidental pollution; 2482 cases of extremely high and high water pollution; noted 35 cases of accidental pollution of water bodies and 5 cases of accidental pollution of soils. In the critical and in almost critical conditions was about $15 \%$ of the territory of Mongolia, more than $56 \%$ of the urban population lives in the capital city with a very high level of air pollution. Over $30 \%$ of the population of Mongolian is not satisfied with drinking water quality, while it was a country that has always been famous for a huge number of sources of clean drinking water.

The main sources ofsoil, water and atmosphere pollutions are the processes of life of modern man, and processes that ensure high quality of urbanized society. It's rather difficult eliminate them: society willhardly voluntarily give up the results of scientific and technological progresses and accelerate the pace of economic development. The only opportunity to try to improve the quality of natural environment - is to intensify efforts on controlling industrial activity, introducing new control technology, and improving the quality of sewage treatment of plants, the creation of new industries to encourage the most environmentally friendly company, introduce new ecologically oriented projects.

In order to achieve business entities with an acceptable level of environmental quality the structure of investment should be changedby increasing the investment to fixed assets aimed at protecting the environment.

There was government funding to the environment projects at the end of XX century in Mongolia. At present time, traditional sources of government budget declined sharply. Government funding is directed mainly to the implementation of targeted programs to eliminate the impact of environmental accidents and disasters. The share of investments in environmental protection, financed from the government budget has decreased. Most of investments are financed by own funds of enterprises and organizations, which is by far the main source of financing investments in environmental protection. In 2014, the share of investment by its own funds of enterprises and organizations amounted to $75.5 \%$, while in 2011 their share was $75.9 \%$ and in 2013 $68.0 \%$. Furthermore, the proportion of government budget aimed at protecting the environment has decreased. So the share of investment in total funds allocated for environmental protection in 2014 was $23.2 \%$, and decreased in relation to 2013 by $6.1 \%$. The share of environmental funds remains low and is only $0.1 \%$ of the total investments in environmental protection and tends to decrease. This ratio is due to the fact that for companies that use natural resources protection of the environment is not a priority for investment. Moreover, not many business entities can afford the payment for environmental activities. One possible solution to the problem of inadequate investment in environment protection may be the introduction of new environmental policy at the 
state level, which will include a system of environmental insurance and state regulations to encourage environmentally friendly production. Therefore, including commercial banks in this process of financing environmentally friendly projects can change this situation.

Despite the resource potential, until today the role of commercial banks in financing investment projects of the real sector in Mongolian economy was not so great, and even fewer resources were invested in environmentally oriented projects.

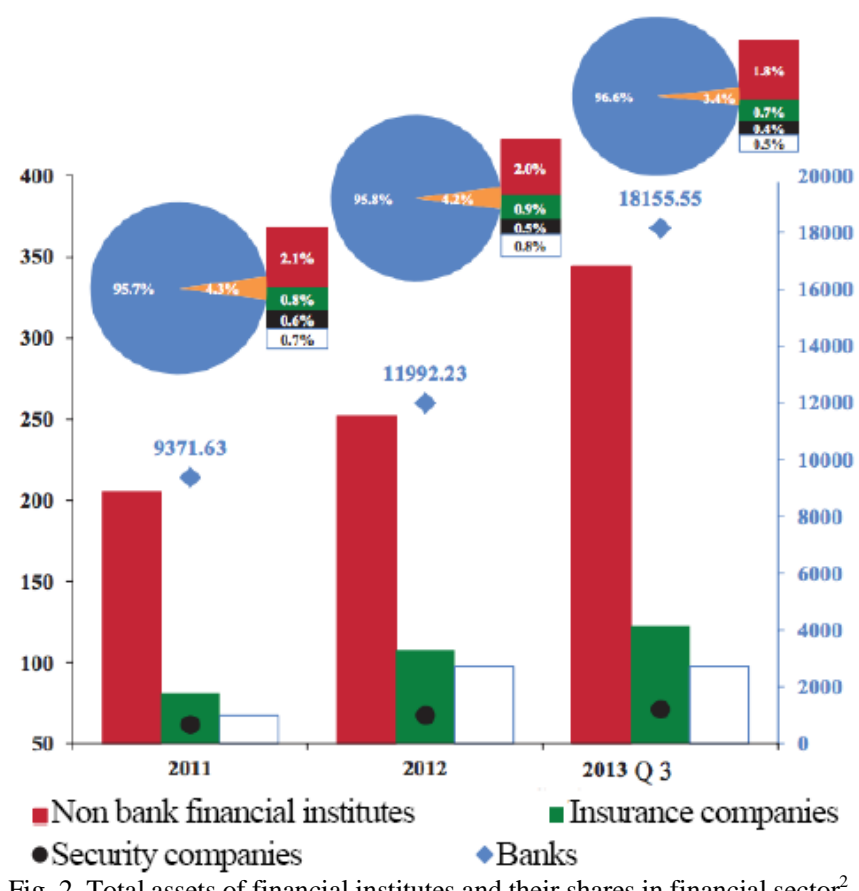

Fig. 2. Total assets of financial institutes and their shares in financial sector ${ }^{2}$.

In 2014, the share of bank loans in the source of financing investment to fixed assets was $6.3 \%, 5.1 \%$ of which were loans to Mongolian banks, and $1.2 \%$-foreign.

However, if in the composition of sources of financing investment projects, bank loans play a modest role, the place of loans granted to non-financial organizations in bank assets is not that much noticeable. Analysis of loan portfolio structure of Mongolian banks shows that loans and other funds granted to national organizations, hold the largest share in it: by 01.01 .2014 it was $60 \%$ and in bank assets as a whole $-43 \%$.

Thus, the volume of bank loans is not closely related to the volume of loans used for investment purposes.

Cash flows of banks can be divided into two groups: commercial and investment. For the effective development of the investment credit organizations need to balance the supply and demand of the real sector. Commercial banks may send their financial resources to environmentally oriented investment projects that allow them to not only solve the problem of cash flow balance, but also fulfill its social responsibility.

Generally, "ecological investment" means financing projects, which result the reduce in amount and harmfulness of emissions, eliminating any sources that could have negative environmental impacts, and investing projects aimed at the greening cities, regions, tourism development

\footnotetext{
${ }^{2}$ Source: Central Bank of Mongolia
}

and environmental protection.

A key indicator do determine the ability of banks to finance investment projects is the loan and investment potential of credit institutions, which means a set of fund sources of bank, that can be directed for investment purposes.

It's possible to analyze the credit-investment potential of the Mongolian banks using the following formula [4]:

\section{$\mathbf{L I P}=\mathbf{O F}+\mathbf{B F}-\mathbf{I A}-\mathbf{R R}-\mathbf{P I}$,}

LIP-loan and investment potential of credit institutions;

OF-own funds of credit institutions;

BF-borrowed funds of credit institutions;

IA-immobilized assets (fixed assets, intangible assets and inventories, portfolio interests in subsidiaries and associated joint stock companies)

RR-required reserve of credit institutions;

PI-premiums of credit institutions in the mandatory deposit insurance fund.

TABLE II: The CREDIT-INVESTMENT Potential of Mongolian BAnKS, MILLION USD ${ }^{3,4}$

\begin{tabular}{lcccc}
\hline \hline & 2011 & 2012 & 2013 & 2014 \\
\hline $\begin{array}{l}\text { The value of credit } \\
\text { investment potential (1) }\end{array}$ & 307,1 & 423,99 & 404,29 & 606,69 \\
$\begin{array}{l}\text { Loans granted to financial } \\
\text { organizations (2) }\end{array}$ & 155,27 & 208,49 & 209,03 & 295,25 \\
Loans granted to residents (3) & 49,5 & 66,95 & 59,56 & 68,08 \\
Securities bought (4) & 28,12 & 29,51 & 53,82 & 61,54 \\
$1-2-3-4$ & 74,21 & 119,04 & 81,88 & 181,82 \\
\hline \hline
\end{tabular}

Thus, from 2011 to 2014 there was a significant increase in credit and investment potential of Mongolian banks, and also loans to organizations have grown. During the calculations, as shown in Table II, were revealed that Mongolian banks can participate in financing investment projects, and even more environmentally oriented projects

Moreover, it is of a great importance to support investment activity in order to develop banks active operations from the government by increasing the volume of guarantees and expanding subsidies on interest rates of investment loans. This is especially related to guaranteed loans for small and medium-sized businesses, agricultural enterprises and defense industry. The most suitable focus is to pay attention on economically promising, with an optimal payback period, environmentally friendly, technologically friendly to the environment projects.

It is also possible a competitive participation in the project of a particular bank or group of banks on the basis of a greater share of resources to invest in an investment project. This practice is effective for building integration links with industrial and banking sector at the regional scale.

Currently loans, granted by commercial banks in Mongolia are not closely related to the amount of loans used for investment purposes. Therefore, in addition to lending to individuals, banks should also devote attention to credit and investment activities. Moreover, selection criteria of investment projects, except those classic factors like profitability and riskiness; banks need to allocate attention to the following points:

\footnotetext{
${ }^{3}$ Source: Analytical report of Mongolian Central Bank

${ }^{4}$ Author's calculation
} 
1) The effect of the project on the main goal of the country, like the survival, development, ensuring the proper functioning of critical systems.

2) The effect of considered investment project on the environment. Banks need to choose from all the projects the one that focus on the development of "green" economy and by this commercial banks will fulfill its social responsibility.

\section{CONCLUSION}

To sum up, through the research it was revealed that, indeed, commercial banks, along with his classic operations may invest in environmentally oriented projects that will allow them to not only effectively manage their resources, but also to fulfill its social responsibility and thereby build confidence in present and future customers.

\section{REFERENCES}

[1] P. F. Kolesov, "The role of investment activity in increasing competitive advantage of banks," Banking Services, vol. 6, June 25-30, 2013.

[2] O. U. Dadasheva, "Investment banking activity and its major trend," Banking, vol. 5, pp. 4-10, May 2014.
[3] M. S. Bolishakova, "Enhancing models of investment banking activity," Banking, vol. 7, pp. 17-23, July 2014.

[4] E. Leontiev, V. V. Bocharovaa, and N. P. Radkovskaya, Investment, 1st ed., 2010, pp. 76-91.

[5] L. G. Batrakova, Economical Analysis in Commercial Banks, M.: Unversity Logos, 2007, pp. 52-80.

[6] Official website of Central bank of Mongolia. [Online]. Available: http://www.mongolbank.mn

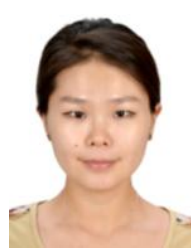

Ganbat Khaliun was born on May 29, 1990 in Ulaanbaatar, Mongolia. She has graduated from a high school in Russian Embassy School in Mongolia in 2008. $\mathrm{Kh}$. Ganbat has been the first in studies at school, she was proposed to take a part in a competition, where $1^{\text {st }}$ places were granted with the right to study in Russian Federation with Russian government budget, so Kh. Ganbat got the best scores and came to Plekhanov Russian University of Economics in Moscow in 2008. She has got bachelor and master degrees in finance and credits in 2013, and since 2014 has been studying for a PhD degree in the Banking Department of Plekhanov Russian University of Economics.

She has worked as a dealer in a Treasury Department in Capitron Bank in Mongolia from May 2012 to September 2012. She has had a trainee in the International Department of Trade and Development Bank of Mongolia from March 2013 to May 2013. Currently she is actively working on her research. She is working now on articles that will be published in Pertanika Journals of Malaysia and Social Science Journal of Thailand, which are members of SCOPUS. Her research interest is investment activity of commercial banks. 